\title{
Adult learning for nutrition security: Challenging dominant values through participatory action research in Eastern India
}

\section{Rama Narayanan \& Nitya Rao}

To cite this article: Rama Narayanan \& Nitya Rao (2019): Adult learning for nutrition security: Challenging dominant values through participatory action research in Eastern India, Studies in the Education of Adults, DOI: 10.1080/02660830.2019.1573782

To link to this article: https://doi.org/10.1080/02660830.2019.1573782

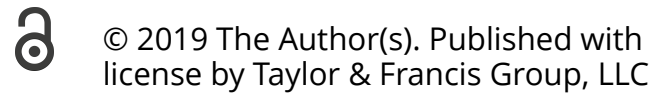

曲 Published online: 01 Mar 2019.

6 Submit your article to this journal

山 Article views: 24

View Crossmark data $\widetilde{\nearrow}$ 


\title{
Adult learning for nutrition security: Challenging dominant values through participatory action research in Eastern India
}

\author{
Rama Narayanan ${ }^{\mathrm{a}}$ and Nitya Rao ${ }^{\mathrm{b} *}$ \\ ${ }^{a}$ Community Nutrition, Chennai, India; ${ }^{b}$ School of International Development, University of East \\ Anglia, Norwich, UK
}

\begin{abstract}
National statistics point to the severe problem of hunger and undernutrition within indigenous communities in India. Several state interventions exist, in terms of both supplementary feeding and nutritional literacy, yet not much progress is visible. This paper explores the experiences of a participatory, educational, action research programme on nutrition for indigenous women and men in Eastern India. Spanning a period of three years, it examines the adult learning approaches involved in the process and their implications for gender relations as well as improved nutritional outcomes. It became clear, that to bring change, the facilitators needed to listen to women's voices and question their own assumptions about ethnicity/caste, class and gender, as well as nutrition. Based mainly on their field reports, this paper seeks to highlight the emergent insights in terms of indigenous women's priorities, their focus on the 'collective', and emphasis on recognition and reciprocity, vis-a-vis institutions of both state and society, articulated during the process of dialogue, reflection, action and learning.
\end{abstract}

\section{KEYWORDS}

Participatory action research; India; nutrition; indigenous women

\section{Introduction}

Given the persistent problem of hunger, food insecurity and undernutrition in the world, as acknowledged by Goal 2 of the Sustainable Development Goals, there is today global recognition that 'nutrition literacy' can play a key role in changing outcomes. The UN Standing Committee on Nutrition notes that 'for all populations, nutrition education and social marketing are crucial components of national, municipal and community efforts for sustained improvements in food and nutrition security' (UNSCN 2010). The UN's Food and Agriculture Organization also emphasizes the need to educate people about eating the right food, besides facilitating a supportive

CONTACT Nitya Rao n.rao@uea.ac.uk $\Theta$ School of International Development, University of East Anglia, 138 Armes Street, Norwich, Norfolk NR24EA, United Kingdom

*Present address: Gender Cross cut lead, LANSA.

(C) 2019 The Author(s). Published with license by Taylor \& Francis Group, LLC

This is an Open Access article distributed under the terms of the Creative Commons Attribution-NonCommercial-NoDerivatives License (http://creativecommons.org/licenses/by-nc-nd/4.0/), which permits non-commercial re-use, distribution, and reproduction in any medium, provided the original work is properly cited, and is not altered, transformed, or built upon in any way. 
environment for healthy balanced diet and lifestyles (FAO 2011, Ecker et al. 2012). Despite this acknowledgement of the importance of nutrition literacy, and a body of evidence that establishes the need for collaborative, flexible and rights-based approaches to literacy, especially when working with indigenous people (Rao and Robinson-Pant 2006), there are few programmes that specifically adopt participatory, adult learning approaches to attain this goal; a majority focus on transmission of information and knowledge on the subject.

In this paper, we focus on a three-year adult learning intervention with indigenous groups in Eastern India, launched in 2012, by an Indian NGO, the M.S Swaminathan Research Foundation (MSSRF). The main objective of the nutrition literacy programme was to create learning spaces for the community to reflect on their nutrition and health practices, specifically the status of women and children, in the context of their groups' histories and identities. The project, using participatory action research (PAR) methods, sought to facilitate a process of action and reflection by community representatives, both women and men, identified as Community Hunger Fighters (CHFs). Through this process, it hoped to help them identify, prioritize and take action, at least in areas under their control, to augment food and nutrition security at the household level. Simultaneously, it was hoped that engagement with the project facilitators would help them gain insights into other knowledge and skills, which could contribute to identifying alternate, collective pathways for claiming their entitlements. Finally, the project hoped to observe and document the transformative process at the individual and community levels as a toolkit for future interventions.

India, lauded as one of the fastest growing economies in the world, performs poorly in the field of hunger and malnutrition. The Global Hunger Index, 2017, ranked India 100 out of 119 countries, with close to $15 \%$ of the total population undernourished; $38 \%$ of under-5 children stunted and $21 \%$ wasted, placing the country is the 'serious' category (IFPRI 2017). A disaggregated poverty analysis in India, reveals that districts with higher proportions of Scheduled Tribe populations, referred to locally and in this paper as Adivasis ('original inhabitants' or indigenous people), are likely to have higher levels of undernutrition as well (Dubey 2009). In fact, according to the Rapid Survey on Children, 2013-2014, Scheduled Tribe children do worse than all other social groups across nutrition indicators (GOI 2014).

The Indian State, which launched a National Nutrition Mission on International Women's Day 2018, has historically provided a range of services to address the problem of hunger and malnutrition. These include social protection measures such as subsidized food grains to the poorest through the Public Distribution System, child nutrition and immunization through the Integrated Child Development Services, nutrition and health literacy through the Accredited Social Health Activists (ASHAs), amongst others. Many of these measures were converted into entitlements under the National Food Security Act, 2013 (http://dfpd.nic.in/nfsa-act.htm). Yet, the nutritional indicators for the Scheduled Tribes in India have worsened over the past three decades (NNMB 2009). Rather than addressing the institutional drivers for this situation, whether a loss of access to common property and forests, changes in cropping patterns involving a shift from millets (a nutritious grain) to eucalyptus plantations, inadequate access to resources and technology for agriculture, low productivity or male out- 
migration for casual wage work in urban centres (Rao and Mitra 2017), state agencies attribute this to 'Adivasi backwardness', and link it to their non-literate status.

This paper, based on an analysis of MSSRF's adult learning intervention, investigates its impacts on both gender relations and nutritional outcomes. It identifies elements of indigenous women's perspectives and knowledge that challenge researcher and elite assumptions and point to a more holistic understanding of nutrition and food security as an element of their life and lifestyle, and of social and gender equality more broadly. The next section sets out our conceptual starting points for the analysis. Section 3 discusses the methodology of the study, while Section 4 sets out the research context and implementation process. Section 5 provides insights into Adivasi women's perspectives and reflections on some of the outcomes in practice. Section 6 concludes.

\section{Conceptual starting points: adult learning for nutrition security}

Adult learning approaches, drawing on the work of the Brazilian educator, Paulo Freire, have for long seen adult education as a process of 'learning to question' (Freire and Macedo 1998:186); a critical understanding of reality; an understanding that emerges from dialogue, and is based on values of equity and justice. Embedded in both a critical process of action and reflection, and in everyday social practice (Lave and Wenger 1991, Street 1984), the very idea of literacy, or adult learning, becomes to change the world, to challenge unjust power relations and transform one's sense of worth (Freire and Macedo 1998: 88, Campbell and Burnaby 2001: 1). The process of working together to unpack the structural features of the experiences narrated is important since it is a way of building relationships and enhancing support, the first step towards collective decisions and action against oppression (Oakley and Marsden 1984).

In the field of nutrition, two broad approaches to adult learning are visible, namely, 'nutrition education' and 'behaviour change communication'. Both seek to transform behaviour but vary in their theoretical underpinnings. The understanding of the first, nutrition education, ranges from helping individuals, families and communities to make informed choices about food (USDA 2012), to planned, educational activities aimed at certain population groups, perceived to be practising suboptimal behaviour from a health and nutrition perspective. In fact, Mcnulty's (2013) observations on nutrition education - that the definitions range from a narrow perception of knowledge dissemination to complex descriptions of a multi-faceted discipline - seem to apply to most nutrition literacy programmes too, which focus on delivering nutrition knowledge rather than creating spaces for a broader discussion of food, health, the body, and the power relations embedded therein.

Behaviour change communication has gained popularity as a research-based consultative process for addressing knowledge, attitudes and practices (UNICEF 2012). It makes strategic use of communication to provide messages and inspiration and uses both interpersonal and mass media channels to help people adopt desired behavioural outcomes (FHI 360 2018). According to UNICEF (2012), individual behaviour change must be accompanied by social change, a process of transformation in the way society 
is organized and power is distributed within various social and political institutions. For this, focusing on individuals is not enough, rather institutional changes that support and promote such behaviour change are required, including the formulation of suitable policies, provision of services or infrastructure, and mechanisms and spaces that allow for questioning of social norms.

Whatever be the definition or terminology used, the key question to consider is how far such interventions enable the creation of 'learning spaces' (Kral and Schwab 2016), where people can critically reflect on their own priorities and knowledge as well as the information and messages they receive through development interventions. How far do they provide fora for questioning hierarchical power relations, reflected in the unequal access to and alienation from their natural resource base, and for women, in particular, invisibility from decision-making processes? For us, nutrition literacy was an entry point for discussions around these broader sets of issues and challenges confronting indigenous women and men in their daily lives and livelihoods. The project, therefore, was not planned to impart information, or even reading and writing skills, but rather understanding local knowledge and practices, the reasons for their disruption, the consequences for health, and possible strategies for addressing the impasse. It was not meant to transfer knowledge but rather facilitate the co-production of socially situated knowledge (Lave and Wenger 1991) through 'access to a range of social, cultural, material, textual, and technological resources and learning spaces' (Kral and Schwab 2016: 474). In striving for individual and socioeconomic transformation through creating a democratic organisation (Campbell and Burnaby 2001), the structure of the programme was flexible, based on participatory and critical pedagogy, that allowed for the emergence and discussion of a range of issues.

Based on a review of fifteen interventions, Shi and Zhang (2011) confirm that successful interventions are those that are 'culturally sensitive, accessible and integrate local resources.' Yet, learner-centred approaches, involving adult learning principles, which acknowledge that the participants bring their own lifetime experiences into the learning processes, are either inadequate or missing in most nutrition education programmes (Vella 2002). People's participation is central to such approaches, however, today the term has lost some of its critical edges and been appropriated by development agencies to meet their programmatic goals (Kothari 2001, Cornwall and Jewkes 1995). Several writers have nevertheless sought to re-appropriate the concept by disaggregating its meanings from nominal and instrumental participation to processes of substantive representation and transformation (White 1996, Cleaver 2001, Mosse 2005). Participation that is transformative has empowerment as its aim; creates an enabling environment for the participants to make their own decisions and set their goals (Kesby 2005). Peoples' participation here becomes a dynamic process, moving beyond participation in development interventions to citizen engagement in local associations, campaigns, formal governance spaces, and so on, in order to make their voices heard and secure their legitimate rights (Gaventa and Barrett 2012).

Perhaps the one criticism of a participatory approach is the lack of adequate attention to gender and other power inequalities, the key to enabling reversals of knowledge and practice (Mosse 1994). Characterised by intersecting power relations of 
gender, race, class, ethnicity, sexuality and age, amongst others (Collins 2009: 8), people experience social inequalities differently, they also organise and respond differently. In fact, gender equality does not imply that women and men do the same things or engage in similar activities, but rather it seeks to ensure that they have equal opportunities to make choices in their lives, to achieve the 'beings and doings' they value (Sen 1999). Given that experiences are shaped by social location and position, and these relationships change over time and space; aspirations, choices and needs are also likely to be fluid (Rao 2017). Further, cooperation is an element of gender relations that is often overlooked (Sen 1990), yet for indigenous women in particular, in a general context of marginality and exclusion, their survival depends on cooperation within the household and the social group to which they belong.

With this conceptualization of adult learning, participation, and gender relations, we turn next to a discussion of the methodology and implementation of the nutrition literacy intervention and draw out key lessons for research, policy and practice.

\section{Methodology and process}

As a research methodology, participatory action research (PAR), draws on concepts of participation and critical action-reflection, to break from the top-down, researcherled model of conventional research. It seeks to bring in local knowledge on equal terms, and contribute to social transformation by challenging power hierarchies (Chambers et al. 1989, Cornwall and Jewkes 1995, Campbell and Burnaby 2001). In line with Freire's approach, the researchers/practitioners focus explicitly on 'empowering marginalized groups to take action to transform their lives' (Cornwall and Jewkes 1995: 1671).

The specific problem we were dealing with was high levels of undernutrition amongst the Adivasis, in particular women and children, in Koraput district, one of the poorest and most under-developed districts in the country. While endowed with rich biodiversity and recognized as the home of several indigenous rice varieties, surveys have shown that it is one of the most food insecure districts in Odisha, with a per-capita calorie intake of $1559 \mathrm{Kcal} /$ day, and the lowest per-capita protein intake of 36 gms/day (IHP and WFP 2008). Fifty-five per cent of children below five years of age were underweight, and 70 per cent stunted, indicating prolonged periods of inadequate food intake (Naandi Foundation 2011).

The action intervention envisaged, therefore, was to work with a group of women and men selected by the community, who would be empowered to critically analyse their own situation of poverty, food and nutrition inadequacy, share their reflections with others in their community, and build strategies to achieve individual and collective wellbeing goals. A three-year process (April 2012-May 2015) of continuous action and reflection was planned with 90 community representatives from 18 villages, referred to as 'Community Hunger Fighters' (CHF). Communities are not homogenous but internally divided by ethnicity, class, and gender, each with their own dynamics and cultures (Table 1). Hence, to represent the heterogeneity, each village was asked to select five persons, whom it trusted, representing different ethnicities or caste groups present in the locality. Further, it was hypothesized that since women's 
Table 1. Programme implementation sites in Koraput district, Odisha State, India.

\begin{tabular}{|c|c|c|c|c|c|c|c|}
\hline \multirow[b]{2}{*}{ S. No } & \multirow[b]{2}{*}{ Villages } & \multirow[b]{2}{*}{ Block } & \multicolumn{5}{|c|}{ Households } \\
\hline & & & ST & SC & $\mathrm{OBC}$ & Others & Total \\
\hline 1 & Baiguda & Kundra & 54 & 13 & 24 & 7 & 98 \\
\hline 2 & Bhatiguda & Kundra & 35 & 51 & 16 & 8 & 110 \\
\hline 3 & Disguda & Kundra & 9 & 125 & 120 & 18 & 272 \\
\hline 4 & Simguda & Kundra & 11 & 28 & 65 & 4 & 108 \\
\hline 5 & Lachnaguda & Kundra & 37 & 8 & 37 & 6 & 88 \\
\hline 6 & Maiguda & Kundra & 34 & 22 & 22 & 0 & 78 \\
\hline 7 & Atariguda & Boipariguda & 2 & 0 & 89 & 0 & 91 \\
\hline 8 & Baiguda & Boipariguda & 107 & 0 & 29 & 0 & 136 \\
\hline 9 & Bheemaguda & Boipariguda & 60 & 14 & 4 & 0 & 78 \\
\hline 10 & Bolguda & Boipariguda & 42 & 13 & 31 & 0 & 86 \\
\hline 11 & Dumaria & Boipariguda & 44 & 2 & 3 & 0 & 49 \\
\hline 12 & Khara & Boipariguda & 0 & 7 & 58 & 0 & 65 \\
\hline 13 & Palli & Boipariguda & 126 & 0 & 2 & 0 & 128 \\
\hline 14 & Cheput & Kundra & 41 & 15 & 47 & 2 & 105 \\
\hline 15 & Pipri & Kundra & 20 & 20 & 49 & 1 & 90 \\
\hline 16 & Gunguda & Kundra & 71 & 5 & 4 & 0 & 80 \\
\hline 17 & Namguda & Kundra & 39 & 0 & 0 & 0 & 39 \\
\hline 18 & Dhartiguda & Kundra & 44 & 0 & 3 & 0 & 47 \\
\hline Total & & & 776 (44\%) & $323(18 \%)$ & $603(35 \%)$ & $46(3 \%)$ & 1748 \\
\hline
\end{tabular}

powerlessness was a key determinant of their undernourished status, sensitization of men along with women, was necessary to help communities in transforming behaviour. Nevertheless, at least two of the representatives from each village were to be women.

The process was triggered initially by a series of residential, training workshops. A range of methods was used to initiate and facilitate discussion from pictorial cards and games to case studies and role plays. These enabled participants to engage in meaningful dialogue, deliberate on personal and social values, norms and relationships, and share their experiences on the conflicts they had faced and how they handled them. The entire training was activity-based, with participants working in pairs, small groups, larger groups, interacting with people from their own and other villages, other genders, castes and ethnic groups, in order to stimulate critical thinking, dialogue and analysis (Freire 1994), while also understanding each other's perspectives. Together with the group of CHFs, the village community could then identify roles and responsibilities and jointly plan the next steps, including, if needed, engagement with wider economic, political and administrative structures, helping bridge the gap between service providers and users. So for instance, while the village development committee was seen to be responsible for the maintenance of checkdams near the village, the supervisors appointed by the Integrated Child Development Services (ICDS) were perceived as responsible for ensuring good quality and reliable service delivery.

The programme was open-ended, on the assumption that one action will flow from the other, responding to needs as they arise, and the sequence will unfold as it went along. A key element of the process was building and nurturing relationships with the CHFs and the community, based on warmth, integrity, trust and empathy. In situations of change, ambiguity and uncertainty, in particular, trust in the person who is facilitating such change is fundamental. Ethical standards in terms of honesty, 
Table 2. Qualitative indicators for programme assessment.

\begin{tabular}{|c|c|}
\hline Parameters & Evidence of outcomes \\
\hline $\begin{array}{l}\text { Building a community resource } \\
\text { base for nutrition security }\end{array}$ & $\begin{array}{l}\text { - critical reflection by participants } \\
\text { - changes in attitudes and perceptions } \\
\text { - } \text { behavioural changes towards food and nutrition security at household level } \\
\text { - } \quad \text { sharing of information and networking with community } \\
\text { effective and responsible utilization of opportunities }\end{array}$ \\
\hline Community action & $\begin{array}{l}\text { - networking by people to discuss issues pertaining to food and nutri- } \\
\text { - } \text { tion security } \\
\text { - collective planning and action for attaining nutritional goals } \\
\text { - } \text { assertive action by marginalized groups such as SC/ST } \\
\text { - forming new or utilizing existing structures for action } \\
\text { - } \text { utilization of new opportunities with mutual cooperation \& accountability } \\
\text { - Emergence of new/collective leadership }\end{array}$ \\
\hline Government entitlements & $\begin{array}{l}\text { - monitoring/effective utilization of existing government programmes } \\
\text { - demand for accountability in Govt programmes } \\
\text { - } \quad \text { indlingness to transact with government officials } \\
\text { - } \text { them sanctioned } \\
\text { - cooperative implementation of collective entitlements }\end{array}$ \\
\hline
\end{tabular}

confidentiality and openness of the project personnel were vital to breaking barriers and creating trust.

As part of the action research process, we sought to assess how far our approach to adult learning had contributed to changing everyday social practices at the household level, or empowered individuals and communities to claim state entitlements for strengthening household nutrition security. Qualitative process indicators were developed, based on participant observation - listening, seeing, questioning and analysis to develop a sense of how power relations were being challenged or not through the process (Ellen 1984). The set of indicators are presented in Table 2. The objective was to use observation to describe the intangible, the relationships between parts, and the underlying connections and meanings (CDRA 1999).

Despite attempts to recruit women investigators, we could not find anyone with a development background, able to work independently, and more importantly, live and work locally. The lone woman candidate who applied, wanted an office rather than a field-based job, hence ultimately two male investigators were recruited, alongside the project coordinator. Each investigator worked with nine villages. They lived close to the village and visited every day, interacting, observing, facilitating and documenting the initiatives of the community. They developed good rapport in the communities, yet issues like menstrual hygiene, pregnancy or lactation, could not be explored in-depth.

The primary source of information was the monthly descriptive reports of the field staff, which were read collectively and subjected to detailed discussion. During this process, if new questions emerged, or there were gaps in understanding, these were clarified through field visits and discussions with the CHFs. Over time, the observations in these reports got sharper. For instance, if reporting a village meeting, the records included not just who and how many were present at the meeting, but nuances on the quality of participation, who spoke, what issues they raised, were views conflicting, and if so, how were they resolved. The investigators also recorded 
verbatim statements during their field interactions. The process of analysis started with free thinking around their observations. These were then grouped into themes such as food security, government entitlements, cropping patterns, coping with disasters, child health etc. The themes were not predetermined, so reflected the local context and changing priorities, especially with season (for example, procuring seeds was the priority before planting, raising money for festivals post-harvest). The quotes presented in this paper were selected to illustrate the nature of discussions on particular themes and the learnings they reveal. Names of villages and individuals have been changed to ensure anonymity.

\section{Research context and implementation}

Adivasis, belonging to the Bhumia, Paroja, Gadaba and Saura communities, considered the most 'marginal' group in Indian society, constitute over 50\% of the total population of the district. The other socially downtrodden group, the Scheduled Castes or Dalits, constitute $14 \%$ of the local population (GOI, 2011). Literacy levels are generally low amongst the Adivasis in the district, more so amongst women $(60 \%$ for men and $38 \%$ for women). Adult literacy levels were very low in our study villages, ranging from one per cent in two hamlets to a maximum of $41 \%$ in one. Most were small and marginal farmers, practising subsistence agriculture, growing rice, millets and some vegetables, primarily for household consumption.

The early period of relationship building and selection of the community hunger fighters was critical since much depended on the community's understanding of the programme. Initial contact with the community was primarily made by the field staff visiting each village several times and holding discussions with different stakeholders including traditional, political and caste leaders, women's groups, and other local institutions. The challenge lay in explaining the programme, as while hunger is widespread in the locality, and well understood; undernutrition is not recognisable or visible. It was therefore not easy to speak about tangible outcomes in terms of nutrition security, or indeed empowerment and transformation in their lives. It was also difficult for people to imagine that years of deprivation could be addressed through a few capacity building exercises.

In order to make the intangible tangible, the project implementers decided to undertake anthropometric assessments of children below three years of age and adolescent girls in all the villages. The results were presented in village meetings. This opened the space for discussion on the causal factors for undernutrition and the potential role the programme could play in facilitating and enriching dialogue and analysis, while also helping people take action at different levels. Following this, it was agreed that five persons would be selected from each village to participate in the programme. While the selection of men was done in a village meeting, with women attending as silent observers, selection of women took place in separate women's meetings. In terms of criteria for selection, for men, the selected person was often an acknowledged leader if possible, socially active, an effective communicator, helpful and smart. In the case of women, the person additionally was someone with older 
children, relatively 'free' of care burdens, and hence the family willing to allow her to participate.

The selection was not always easy as gendered perceptions of the programme came into play. Health and nutrition are generally perceived as women's issues, while production or technology are seen as relevant to men. In several villages, such as Cheput and Namguda, initially only women were selected, the argument being that men were already part of other interventions, such as use of the power tiller, promoted by the same NGO. Only after considerable debate did some men agree to join. There was also a class issue, with hunger and nutrition seen as problems of the poor; better off women were more interested in joining groups that could help them access government loans. However, finally, of the 90 selected, 39 (44\%) were women and the rest men. Forty-seven participants (52\%) were Adivasis, though there were variations across villages. For instance, while Cheput had an equal number of Adivasis and other communities in its population, only one of the selected persons was an Adivasi. In Simguda and Pipri, on the other hand, though dominated by other communities, most of those selected were Adivasis. Ultimately, the selection depended on perceptions of who was acceptable to the community, but also on the individual's life-stage and family obligations. In fact, class and gender biases had to be discussed and addressed throughout the process.

Following selection, a residential training programme was the initial 'trigger' activity in the reflection process followed by subsequent, demand-driven capacity building exercises. The residential training provided an opportunity for the participants to stay together, share common facilities, discuss issues pertaining to their villages and critically reflect on ways of improving the quality of life for themselves and their communities. While in real life, social spaces as well as interaction between people are defined by considerations of ethnicity, caste and gender, the residential programme created space for equal participation and learning, encouraging people to speak up freely on the existing social scenario and its impacts on their everyday lives, including their health and nutritional status.

The residential programme, completed between February and April 2013, was designed in three modules, each lasting two and a half days. A gap of 15-20 days was provided between modules, to enable participants to try and relate the learning experiences to their daily lives. The principal trainers were women while the male project personnel also participated in the discussions. The first module dealt with the concept of diets and the nutrients therein and exposed participants to various techniques used in nutritional assessment such as anthropometry, clinical and biochemical analysis. Demystification of technologies was considered essential for people to gain confidence and effectively utilize health programmes. The second module presented 21 Government entitlements, including direct food-based schemes such as the School Midday Meal and the ICDS, giving an insight into possibilities for claims-making. It also enabled discussions on peoples' participation in local self-governance mechanisms and class, caste and gender perceptions (c.f. Campbell and Burnaby 2001). The third module was envisaged to help participants identify individual as well as community goals for achieving nutrition security. Prioritization of tasks and identification of further capacity building needs were built into the programme. While most sessions 
were common for all participants, the theme on menstrual hygiene had to be discussed separately with the women for reasons of cultural appropriateness.

\subsection{Critical reflection during residential training}

Four themes were explored in-depth by the participants during the residential workshops: the relationship between nutrition and their social conditions, value systems pertaining to class, caste and gender, participation in village development and demystification of technology. In one exercise, the participants used pictures of food groups to analyse their daily diets, what they ate once in a fortnight and what they ate occasionally. During the discussion, the women realised that they were only consuming two-three food groups regularly. This also varied by caste, hence they started relating aspects of their life and the values they held to their food habits. For instance, under the influence of a Hindu priest, the Bhumia Adivasis, especially women, had taken to regular fasting, while at the same time giving up nonvegetarian food (Mitra and Rao 2018). They reflected on the fact that they hardly ate on time, especially during the peak agricultural seasons, when they were immersed in work. Lack of time for cooking meant that they managed with rice and tamarind paste (Rao and Raju, forthcoming). While they produced food, they usually sold the good quality grains in the market and ate only those of a lower grade. This exercise helped them realize how little priority they gave their health; the motivation for eating was to fill their stomachs. Poverty was not a real constraint, as there were a number of small things they could do to eat and live better, even within their own contexts and constraints. The programme personnel too, who had this far considered local availability of food to be the major determinant of food intake, learnt that people's everyday lives, their priorities, beliefs and value systems played a key role in influencing food consumption.

The nutritional assessment revealed that most of the women were undernourished. This led to a discussion of existing inequalities and how they affected women's health. Participants identified some of the common causes including working without taking rest, especially during pregnancy, getting back to work within a few days of delivery and lack of health care during pregnancy. Further, women identified poor quality drinking water and lack of sanitation as important determinants of poor health and nutrition. As one woman participant remarked 'All our problems will go away if we have good water. Either we or the girl children are always doing the job. It is high time our authorities gave us water'. The issue that touched them the most was of young child undernutrition. Several participants said, 'while we know children have to be cared for, we never knew that undernutrition during this period can cause so much damage throughout life;' 'We never knew birthweight was so important'; 'Children are our greatest wealth. We cannot let anything happen to them'; or 'Both male and female babies are affected if women are weak. The welfare of the entire society rests on the welfare of women'.

The subject of toilets generated the most heat between women and men participants. While everyone agreed that open defecation posed a public health hazard, men initially argued that the lack of toilets was a problem only at night. However, women 
argued that they faced several hardships, such as loss of modesty, hygiene issues during menstruation and difficulty during pregnancy and lactation. During the course of the discussion men agreed that 'we never thought of it this way till now'.

Since nutritional status assessment of all participants was carried out during the residential training it helped to understand the science behind the technologies. For some, it proved an opportunity to overcome fears. The child growth chart generated a lot of interest among women and the interpretation of its plotting and marking were eagerly sought. The State Coordinator of the ICDS gave an overview of the programme, leading to a lively discussion. The participants raised questions on provisioning, implementation and grievance redressal mechanisms. In the final module, the participants developed several messages and action points relating to sanitation, complementary feeding, empowerment of women and the need for unity for village development.

\subsection{Further capacity building}

As an offshoot of the residential training, participants identified further training needs, and capacity building exercises continued throughout the project period. These ranged from exposure visits to community models for nutrition security and technical training in agriculture to interfaces with the Collector and other Government officials to better understand how entitlements could be secured. A total of 12 sessions were organized, the purpose ultimately was to expand the range of possibilities and strategies open to them, both individual and collective.

These sessions had a further aim, namely, to provide learning spaces to additional people from the community, as the originally selected CHFs could not always attend all the training programmes for a host of reasons. Apart from events such as marriages and deaths, many women in particular encountered personal problems such as illness of a family member, or non-cooperation by families. Given the precarity of their lives, sudden changes in economic status were also common. Paro Majhi, a woman CHF, had borrowed money, and as she was unable to repay it on time, she had to serve as a 'bonded labour' for a year at the home of the moneylender. She lost all control over her own labour and time and could not participate as a result. There was also an issue of interests and preferences. Trainings on seed treatment were of particular interest to women since seed conservation was considered a woman's job, while the Mali community, traditional vegetable cultivators, took a lot of interest in discussions around vegetable cultivation. Similarly, women's participation fell in exposure visits, as they could not stay away from their homes for more than three days at a stretch. Yet the CHFs soon became quite strategic, so when a visit was organized to a water and sanitation programme, they wanted the elected local government representatives to accompany them, as they could then follow up on such public works.

In short, the entire training programme, whether residential or follow-up, was organized in consultation with the selected CHFs. While $90 \mathrm{CHFs}$ were selected as participants at the start, due to replacements and additions, a total of 155 persons participated over the course of the programme. Women's participation increased 
from an initial 39 to 69 , with the ratio of women and men becoming almost equal in most villages.

\section{Indigenous women's perspectives on food and nutrition security}

Through the process of dialogue, discussion and critical reflection, the participants enhanced the scope of nutrition security, to move beyond food availability, access and absorption (FAO 1996), to include concepts of consumption and a healthy lifestyle. As some of the women participants said, 'what is the point in growing food if we do not eat ourselves.' Reminiscing about eating stale and leftover food instead of fresh food, one male participant remarked, 'We thought satisfying our hunger was enough. Now we are conscious of bringing in dietary diversity and eating all seasonal foods'. While analyzing food habits, it emerged that Adivasi women, as compared to other caste groups, had greater knowledge about 'wild' or uncultivated foods and the potential these offered for enhancing dietary diversity. However, they rued the decline in forest cover, and the gradual take-over of forest lands, and also their own uplands, where they earlier grew millets and vegetables, by eucalyptus plantations. Eucalyptus brought in cash incomes, but this was used for bulk expenses like repairing their house or paying school fees. They lost a source of food and nutrition (Rao and Mitra 2017). Interestingly, and surprisingly for us, in the discussions around consumption, Adivasi women suggested activating their village forest protection committees, as access to forests and common property resources they felt was central to their nutrition security.

Women further opined that lifestyle patterns such as chewing of tobacco and alcoholism posed potential health hazards. A critical discussion took place on this issue between the women and men participants. Men challenged women on the consumption of alcohol, claiming that women too drank. The women replied that they drank neither on a daily basis nor spent an entire day's wages or the household grains on liquor and never to such an extent that they were dysfunctional. What was clearly beginning to emerge during the dialogue and reflection was that nutrition security was not just a technical issue, nor was it an individual one. It needed attention at both relational and collective levels, in values, practices and 'interfaces' with the state and economy. Women realised that they could not bring change on their own, so strategically sought to bring in male leaders, staff and CHFs, hoping to 'enrol' their support for their own projects (Long and Long 1992). They invited those men whom they could trust in their meetings, and in one village secured their support for raising the issue of childcare with the local administration. They also sought their support where larger issues such as forest conservation or claiming accountability from state services were involved.

From the recorded observations, we analysed the changes visible at the individual level of the CHFs and their households, but also the community, especially the steps taken towards challenging the existing 'doxa' and transforming norms around gendered responsibilities and voice (c.f. Bourdieu 1977). We focus next on women's strategies for building bridges with their own men, as well as women of other groups. 


\subsection{Changing practices: individual and collective}

At the individual level, 23 observations were recorded under three dimensions of nutrition identified during the workshops, namely, actions for improving dietary diversity, personal hygiene practices, and child health and nutrition. Within each of these dimensions, the specific activities varied, in line with the resources available and the possibilities the CHFs saw for making changes in their lives. Thirteen observations pertained to efforts to consume a diverse diet, but each of them was different. While several changed their agricultural practices and started growing more vegetables and fruits, one woman had to get her land back from lease for this purpose, one landless CHF had to lease in some land, and another landless woman started growing vegetables in the foundation of the house she was constructing. She said 'now it is going to be monsoon. No construction will take place for a few more months. I might as well use the space for growing vegetables for my consumption.' One CHF brought in crop rotation in her field and also started tending to the kitchen garden, while a fifth, who was selling mangoes and papayas, started to keep some for her own consumption.

With assured security of land, men tended to focus on improving the productivity of their agriculture. Two of them had taken steps to ensure irrigation facilities to enable cultivation throughout the year. Women's strategies were different, as not only did they not have independent land titles, but their customary rights to uplands too were being rapidly eroded (by eucalyptus plantations). Women were additionally burdened with the responsibility for domestic and care work. Yet the CHFs, women and men, were keen to compare notes and support each other's practices in whatever way possible.

In the second area concerning personal and environmental hygiene, handwashing and keeping the house clean were identified by several of the CHFs as central to improving nutrition. They began using terms such as 'insist on hand washing', 'very strict about hand washing with the family,' and so on. One of the male CHFs from Simguda took a lot of pride in his action, noting that 'I brought the childcare (Anganwadi) worker and showed her how clean the house was'. Mangal Paroja of Baiguda got his child weighed at the Anganwadi centre, and when the child was found to be severely underweight, started looking for solutions. Here the traditional image of the child being 'women's business' was deconstructed, with men beginning to play active roles in child health and nutrition, albeit through their engagement with external institutions, be it the Anganwadi or the health centre. While men perhaps had not yet started contributing, at least equally, to the performance of the daily chores of cooking, cleaning, bathing children and washing, they were beginning to acknowledge that these were important tasks for nutrition security and needed to be recognized and supported. Giving visibility to the unequal gender division of labour and initiating critical discussions around care work as central to nutrition security, was a first step in redistributing work and responsibilities more equitably within households and communities (c.f. Razavi 2007, Rao 2018).

The uniqueness of these actions and the manner in which they were done reiterate the limitless possibilities of reflective action that is not likely to be facilitated in a 
formal education programme. While men's growing engagement in child nutrition and health was a positive development, it also brought out the structural constraints confronting women. First, while each village had several women's groups that were supposed to facilitate women's participation in social and developmental activities, they were only perceived as loan servicing institutions and not as platforms for empowerment. Secondly, women were unable to participate meaningfully in village meetings, as they were relegated to the back and their voices remained unheard. Finally, nutrition interventions by development agencies generally stereotype gender roles, providing men with technological training, and women cooking demonstrations. The curriculum and pedagogy is generally inflexible, and fails to seriously engage with indigenous women's knowledge, or indeed priorities and practices.

After the residential training, the women CHFs started discussing issues of health and nutritional status of children and adolescent girls in the women's group meetings. Visualizing child health (using the growth chart) as central to community welfare, they collectively identified village development issues such as safe drinking water, sanitation, clean environment, functioning schools and child care centres, basic infrastructure including good roads, improved agricultural production, addressing the problems of alcoholism and unemployment, in this order of priority, as key inputs towards nutrition security. Some women's group leaders, CHFs and women ward members started mobilizing women in large numbers to attend village level meetings.

The CHFs of Cheput wanted to revive the defunct village development committee (VDC). With the support of the women's groups and the male CHF, they mobilised both the women and men to attend a meeting in July 2013. Of the 37 who attended, 29 were women. In the meeting, new office bearers were elected, with a mandate to collect monthly subscriptions for village development work. They decided to demand better facilities for the local childcare centre, revive activities undertaken by the Forest Protection Committee, and start a seed and grain bank for collecting, storing and lending seeds and grains to needy households. In this entire process, two distinct shifts could be identified. First, through a conscious process of dialogue, organising and decision making, a male-dominated peoples' institution saw the control of resources shifting from men to women.

The second shift related to the meaningful, and not just equal, participation of women in changing the social reality of their lives, addressing areas of concern they had identified. On April 1st 2014, SHG (self-help group) members met and decided to ask nine families in Dhaniguda village, preparing and selling country liquor, to close down their shops, given the nuisance created by their clients. The women of Khara village took the initiative to organize other women in their own and neighbouring villages. On the 3rd morning, 35 women from these villages asked the concerned families to stop commercial sale of liquor, however, the families refused. On 5th April, a large number of women again met the families, who now asked for a week's time to wind up their operations. After waiting 10 days, when there was no sign of closure, about 100 women marched to the premises where liquor was being brewed and broke the pots. While four families stopped all operations, one continued defiantly. In May 2014, a large number of women along with some male villagers proceeded to the Sub-collector's office to lodge a complaint. On his advice, they filed 
a police complaint and waited for further action. Not just did the Adivasi women, led by the CHFs, take a lead, but were also able to gain male support in order to take their action beyond the boundaries of their village.

Great priority was given to improving the delivery of childcare services at the Government-run Anganwadi centres through regular monitoring, conflict resolution through dialogue and by providing material and physical support to the personnel. Parvathy Majhi, the woman CHF of Palli, moved to a house close to the Anganwadi and started monitoring the services, ensuring that the worker, who used to come once a week, came regularly. In fact, some of the male CHFs, conscious of their own privileged position, and recognising the constraints faced by women, actively pursued the implementation of the ICDS, recognizing its significance for child care, health and nutrition, while their women were working.

All eighteen villages prepared 'action plans' for ensuring nutrition security wherein they gave voice to both individual and collective entitlements. This required mobilization of traditional leaders, elected representatives, members of village committees as well as women and men from individual households. Women used the SHG space to discuss their priorities and agendas and attended village meetings in large numbers. Male CHFs, such as Arjun, who owned a teashop in Dumaria, not only started discussing nutrition issues with his clients but also prevailed upon the community members to accommodate women's needs in the village development plan. They convened village meetings at times convenient for women and invited the women CHFs to address the gathering. As one male CHF put it, 'it served two purposes, one in helping women to get a leadership role and the other to avoid ridicule from fellow villagers that 'men' chose to speak about issues of childcare and sanitation'.

Several male CHFs took an active role in involving women in village development issues including when applying for Government entitlements such as toilets. While very few households had toilet facilities at the start of the project, $64 \%$ across the 18 villages had applied for Government subsidy to build toilets by the end. During the project period, seven villages secured the sanction and in three the constructions were completed. One finds here growing cooperation and indeed relations of respect between women and men in dealing with common problems that affect their wellbeing.

Women also started creating their own spaces, supporting each other in their personal lives. Samari and Ghasma in Baiguda actively reached out to other women, resolving conflicts between husband and wife, and in the process gained considerable respect. Clearly here learning in one sector was being internalised and applied to all aspects of women's lives. Encouraged to air their views and engage in dialogue, they also sought respect and dignity in their everyday lives. The learning was not just about improving indicators but embraced issues of power and inequality more broadly.

\section{Some tentative conclusions}

This paper has presented some insights into adult learning programmes for indigenous women (and men) that facilitate processes of action and reflection through 
examining a nutrition literacy project. Technical fixes have clearly not worked, as evident in the case of India, where food and nutrition interventions have existed for several decades. For change to occur, it is important to understand and give voice to indigenous women's perspectives and knowledge through flexible and responsive learning approaches, as nutrition security entails a complex interwoven web of technical, social, ethical and political considerations.

The participatory action research project, involving indigenous women and men as 'Community Hunger Fighters' highlighted the links between adult learning, gendered power relations, and action for nutrition security, be it with respect to control over common property resources, addressing women's time and work burdens, or giving them an equal say in decision-making at the community level. Women resented the fact that state institutions responded to men's complaints on the poor functioning of the Anganwadis, for instance, rather than their own, yet in the short-term, they sought male support for attaining these goals. While 'critically conscious' of the issues they confronted (Freire 1994), they were able to effectively strategise to ensure the outcomes they desired. Empowerment here was central to their learning processes.

While the discourses on nutrition education and behaviour change do speak of social transformation, this vision needs to be put into practice as a bottom-up, collective process, contextually and spatially embedded, addressing local power dynamics by first 'naming (it) within educational settings' (Campbell and Burnaby 2001:3). Since communities are not homogenous, the project underscored the need for representative participation based on class, caste and gender, consciously maximizing opportunities for the 'marginalized', while at the same time, 'enrolling' those with more power to help fulfil these 'projects' (Long and Long 1992). While 'participation' may be critiqued, it continues to provide spaces for learning, collective action, and resisting structures of oppression (Kesby 2005) and was central to the success of the intervention.

Initiating collective community action needed a trigger and this was provided by the CHFs sharing the ideas generated and discussed in the residential training in formal group and village meetings, informally in tea shops, agricultural fields and in places where people converged, as well as with individual households. Their efforts were manifest in different planes, namely, in revitalizing existing social institutions to move towards a broader development agenda sensitive to nutrition security, in demanding and utilizing legal entitlements to food and nutrition, and in challenging existing social norms with regard to caste, class, gender and leadership. A key adult learning principle is the relevance of the issue to the lives of the community, women and men, and hence their desire to put their learning into practice.

Learning here incorporated both formal and informal acquisition; it developed a meaning and purpose in their everyday lives through the visible link to health and wellbeing, especially of their children. Multimodal forms of communication were used from anthropometric measurements and growth charts to more open-ended discussions of social problems, labour arrangements and resource access. While the structural power of the state and markets are not easy to confront, we hope that the 
creation of learning spaces facilitated by the CHFs, will help forge partnerships to enable empowered action for a better life, including meeting their goals of nutrition security.

\section{Acknowledgements}

This paper is derived from the report entitled 'Towards Nutrition Security - Community Hunger Fighters Programme' authored by Rama Narayanan, Tusar Ranjan Nayak, Sanjay Kumar Swain and Ramachandra Tosh that outlines an adult nutrition literacy project implemented in Odisha by the M S Swaminathan Research Foundation with financial support from Global Alliance for Improved Nutrition (GAIN). Insights from subsequent work on women in agriculture and nutrition in the same area under the research programme on Leveraging Agriculture for Nutrition in South Asia has been drawn on to set the context. Apart from the CHFs and other community members who shared with us their views and insights, we would like to thank the two anonymous reviewers and the editors of the special issue for their comments.

\section{Disclosure statement}

No potential conflict of interest was reported by the authors.

\section{Funding}

This study was implemented in Odisha by the M S Swaminathan Research Foundation with financial support from Global Alliance for Improved Nutrition (GAIN). The contextual analysis for this paper was also supported by Leveraging Agriculture for Nutrition in South Asia (LANSA), an international research consortium funded by UK aid from the UK Government (Department for International Development).

\section{ORCID}

Nitya Rao (D) http://orcid.org/0000-0002-6318-0147

\section{References}

Bourdieu, P., 1977. Outline of a theory of practice. Cambridge: Cambridge University Press.

Campbell, P., and Burnaby, B., 2001. Participatory practices in adult education. New York and London: Routledge.

Chambers, R., Pacey, A., and Thrupp, L. A., 1989. Farmer first: farmer innovation and agricultural research. London: Intermediate Technology Publications.

Cleaver, F., 2001. Institutions, agency and the limitations of participatory approaches to development. In: B. Cooke and U. Kothari, eds. Participation: the new tyranny. London: Zed Books, 36-55.

Collins, P.H., 2009. The new politics of community. American sociological review, 75 (1), 7-30.

Community Development Research Association (CDRA). 1998-1999. Development Practitioners - Artists of the Invisible, Annual Report.

Cornwall, A., and Jewkes, R., 1995. What is participatory research? Social science and medicine (1982), 41 (12), 1667-1676. 
Dubey, A., 2009. Poverty and under-nutrition among scheduled tribes in India: a disaggregated analysis IGIDR proceedings/project reports series PP-062-13. Mumbai: IGIDR. Available from: http://www.igidr.ac.in/pdf/publication/PP-062-13.pdf

Ecker, O., Bresinger, C., and Pauw, K., 2012. Growth is good, but is not enough to improve Nutrition. In: S. Fan and R. Pandya-Lorch, eds. Reshaping agriculture for nutrition and health. Washington D C: International Food Policy Research Institute. Available from: www. ifpri.org/sites/default/files/publications/oc69.pdf

Ellen, R. F., 1984. Ethnographic research. London: Academic Press.

Food and Agricultural Organization of the United Nations (FAO), 1996. Declaration on world food security. Rome: FAO.

FAO, 2011. The state of food and agriculture, 2010-11. Women in agriculture: closing the gender gap for development. Rome: Food and Agriculture Organisation.

FHI 360, 2018. A 360 degree approach to social and behaviour change. Available from: https:// www.fhi360.org/resource/360-degree-approach-social-and-behavior-change

Freire, A. M., and D. Macedo, eds, 1998. The Paolo Freire reader. New York: Continuum.

Freire, P., 1994. Pedagogy of hope: reliving pedagogy of the oppressed. New York: Continuum.

Gaventa, J., and Barrett, G., 2012. Mapping the outcomes of citizen engagement. World development, 40 (12), 2399-2410.

GOI (Government of India), 2011. Census of India Population of Koraput District of Odisha, Census office. Available from: https://www.census2011.co.in/census/district/422-koraput.html [Accessed 20 Nov 2018].

GOI (Government of India), 2014. Rapid Survey on Children 2013-2014 Fact Sheets. Ministry of Women and Child Development. New Delhi. Available from: http://wcd.nic.in/acts/rapidsurvey-children-rsoc-2013-14 [Accessed 20 Nov 2018].

IFPRI, 2017. Global hunger index: the inequalities of hunger. International Food Policy Research Institute. Washington D.C. Available from: http://www.ifpri.org/publication/2017global-hunger-index-inequalities-hunger [Accessed 10 Dec 2018].

IHP (Institute for Human Development) and WFP (World Food Programme) 2008. Food Insecurity Atlas of Rural Orissa. WFP, New Delhi. Available from: https://www.wfp.org/content/india-food-security-atlas-rural-odisha-2008 [Accessed 20 Nov 2018].

Kesby, M., 2005. Retheorizing empowerment-through-participation as a performance in space: beyond tyranny to transformation. Signs, 30 (4), 2037-2065.

Kothari, U., 2001. Power, knowledge and social control in participatory development. In: B., Cooke and U. Kothari, eds. Participation: the new tyranny. London: Zed Books, 139-152.

Kral, I., and Schwab, R.G., 2016. A space to learn: a community-based approach to meaningful adult learning and literacy in remote indigenous Australia. Prospects, 46 (3-4), 465-477.

Lave, J., and Wenger, E., 1991. Situated learning: legitimate peripheral participation. Cambridge: Cambridge University Press.

Long, N., and Long, A., 1992. Battlefields of knowledge: the interlocking of theory and practice in social research and development. London: Routledge.

Mcnulty, J., 2013. Challenges and issues in nutrition education. Rome. Nutrition education and consumer awareness group. Food and Agricultural Organization of the United Nations. Available from: www.fao.org/ag/human nutrition/nutrition education/en/ [Accessed 20 Nov 2018].

Mitra, A., and Rao, N., 2018. Gender, food-cultures, nutrition and religious nationalism. Lansa Draft Paper. MSSRF. Chennai. (under review).

Mosse, D., 1994. Authority, gender and knowledge: theoretical reflections on the practice of participatory rural appraisal. Development and change, 25 (3), 497-526.

Mosse, D., 2005. Cultivating development: an ethnography of aid policy and practice. London: Pluto Press.

Naandi Foundation 2011. HUNGama: Fighting hunger and malnutrition. The HUNGama Survey Report, Hyderabad. 
National Nutrition Monitoring Bureau (NNMB). 2009. Diet and nutritional status of tribal population and prevalence of hypertension amongst adults: Report on second repeat survey. NNMB Technical Report No. 25. Hyderabad: National Institute of Nutrition.

Oakley, P., and Marsden, D., 1984. Approaches to participation in rural development. Geneva: ACC Task Force on Rural Development, ILO.

Rao, N., and Robinson-Pant, A., 2006. Adult education and indigenous people: addressing gender in policy and practice. International journal of educational development, 26 (2), 209-223.

Rao, N., and Mitra, A., 2017. Understanding transitions in gendered work and care in a fragile ecosystem of Eastern India. Paper presented at workshop on 'Sustainability, Ecology and Care,' Friedrich Ebert Stiftung, Berlin. Jan 19-20, 2017.

Rao, N., and Raju, S., forthcoming. Gendered time, seasonality and nutrition: Insights from two Indian districts. Feminist Economics (accepted for publication)

Rao, N., 2017. Assets, agency and legitimacy: towards a relational understanding of gender equality policy and practice. World development, 95, 43-54. http://dx.doi.org/10.1016/j.worlddev.2017.02.018.

Rao, N., 2018. Global agendas, local norms: mobilizing around unpaid care and domestic work in Asia. Development and change, 49 (3), 735-758.

Razavi, S., 2007. 'The Political and Social Economy of Care in a Development Context'. UNRISD Gender and Development Programme Paper 3. Geneva: United Nations Research Institute for Social Development.

Sen, A., 1990. Gender and cooperative conflicts. In: Irene Tinker, ed. Persistent inequalities: women and world development. New York: Oxford University Press, 123-149.

Sen, A., 1999. Development as freedom. Oxford, UK: Oxford University Press.

Shi, L., and Zhang, J., 2011. Recent evidence of the effectivenesss of educational interventions for improving complementary feeding practices in developing countries. Journal of tropical paediatrics, 57 (2), 91-98.

Street, B. V., 1984. Literacy in theory and practice. Cambridge: Cambridge University Press.

UNICEF (United Nations International Children's Emergency Fund) 2012. Communication for Development, Behaviour and Social Change. Available from: www.unicef.org/cbsc/index 42352.html [Accessed 15 Nov 2018].

UNSCN (United Nations Standing Committee on Nutrition). 2010. Progress in Nutrition. 6th Report on the World Nutrition Situation, Geneva.

USDA 2012. Nutrition website, National Institute of Food and Agriculture. Available from www.nifa.usda.gov/nutrition.cfm [Accessed 15 Nov 2018].

Vella, J., 2002. Learning to listen, learning to teach: the power of dialogue in educating adults. San Francisco, CA: Jossey-Bass. (Cited in Mcnulty J 2013. Challenges and issues in nutrition education. Rome. Nutrition education and consumer awareness group. Food and Agricultural Organization of the United Nations).

White, S.C., 1996. Depoliticising development - the uses and abuses of participation. Development in practice, 6 (1), 6-15. 